\title{
Estimation of Carbon Stock Changes in Above Ground Woody Bio- mass due to Volcano Pyroclastic Flow and Pyroclastic Surge
}

\author{
Selli Fidi Yani Wardani, L. M. (Louise) M. van Leeuwen
}

Received: 2205 2014/ Accepted: 2905 2014 / Published online: 30062014

(c) 2014 Faculty of Geography UGM and The Indonesian Geographers Association

\begin{abstract}
Merapi Volcano National Park (MVNP) is susceptible to volcanic hazard since it is located around Merapi volcano, especially pyroclastic flow. Carbon sequestration in the national park is becoming a priority of forest development as stipulated in Government Regulation Number 28 Year 2011 and Number 49 Year 2011. This study aims to know the effect of pyroclastic event to carbon stock in MVNP. In this study the natural carbon rate recovery in MVNP was estimated to determine the growth rate of natural carbon recovery in MVNP. To estimate carbon stock change in MVNP, 2006 QuickBird and 2011 GeoEye satellite imageries were used. Object based image segmentation of high resolution satellites imagery could recognize physical dimensions of individual trees such as crown projection area (CPA). In this study, carbon stock was derived using allometric equation based on measured diameter at breast height (DBH) in the field. A model was developed to estimate carbon stock based on DBH estimation in the field and segmented CPA from the image. Based on the segmentation process, the model of CPA and Carbon in MVNP was developed. The F score which indicate the accuracy of segmentation of needle leaf and broadleaved of 2011 GeoEye were 0.68 and 0.54 respectively. Logarithmic model which has $6.37 \%$ error was used to estimate broadleaved carbon stock while quadratic model which has $10.31 \%$ error was used to estimate Pine tree carbon stock in MVNP.
\end{abstract}

Keywords: Merapi Volcano National Park, carbon stock, crown projection area.

Abstrak Taman Nasional Gunung Merapi (TNGM) memiliki kerawanan yang tinggi terhadap ancaman bahaya vulkanik karena terletak di sekitar Gunung Merapi, terutama akibat aliran piroklastik. Penyerapan karbon di taman nasional ini menjadi prioritas pengelolaan hutan sebagaimana diatur dalam Peraturan Pemerintah Nomor 28 Tahun 2011 dan Nomor 49 Tahun 2011. Penelitian ini bertujuan untuk mengetahui pengaruh aliran piroklastik terhadap stok karbon di TNGM. Dalam penelitian ini, pemulihan karbon alami di TNGM diperkirakan untuk menentukan tingkat pertumbuhan pemulihan karbon alami. Untuk memperkirakan perubahan stok karbon di TNGM, digunakan citra QuickBird tahun 2006 dan GeoEye tahun 2011. Segmentasi citra berbasis obyek menggunakan citra resolusi tinggimampu mengenali dimensi fisik pohon secara individu, misalnya Crown Projection Area (CPA). Dalam studi ini, stok karbon diperoleh menggunakan persamaan alometrik berdasarkan Diameter at Breast Height (DBH) di lapangan. Sebuah model dikembangkan untuk memperkirakan stok karbon berdasarkan estimasi DBH di lapangan dan CPA tersegmentasi dari citra. Berdasarkan proses segmentasi tersebut, dikembangkan model CPA dan Karbon di TNGM. Hasil F skor menunjukkan akurasi segmentasi vegetasi berdaun jarum dan berdaun lebar pada citra GeoEye 2011 adalah 0,68 dan 0,54. Model logaritmik memiliki nilai error 6,37\% dan digunakan untuk memperkirakan stok karbon vegetasi berdaun lebar, sedangkan model kuadrat dengan error 10,31\% digunakan untuk memperkirakan stok karbon tanaman pinus di TNGM.

Kata kunci: Merapi Volcano National Park, stok karbon, area proyeksi mahkota.

\section{Introduction}

Climate change is indicated by warmed of global system. This phenomenon is strengthened by the Intergovernmental Panel on Climate Change (IPCC) study [2007] that shows the increase in average temperature of air and ocean, the melting of snow and ice and the rise of global average sea level. The main cause of climate change is the increase of green house gasses (GHG) in the atmosphere. $\mathrm{CO}_{2}$ is the main GHG which is sourced from the burning of fossil fuel,

Selli Fidi Yani Wardani

Ministry of Forestry, Republic of Indonesia

Email: molliy_manies@yahoo.com

L. M. (Louise) Van Leeuwen

Faculty of Geo-information Science and Earth Observation, University of Twente, the Netherlands agriculture, and land use changes and deforestation [IPCC, 2012].

One way to control climate change and to reduce green house gas increase is to maintain the integrity of natural forests and increase the density of trees outside the forest. Vegetation is a carbon sink which stores more carbon than it emits. Forest is the best carbon sink since it stores carbon in large amounts [IPCC, 2007]. Natural hazards such as volcanic hazard are natural phenomena which can reduce the amount of carbon stored in vegetation because it can cause the death and disintegration of vegetation/biomass.

Merapi volcano is one of the most active volcanoes in Indonesia, well known for its pyroclastic flow. Merapi volcano erupts 4-6 years periodically since 19th century 
with Volcanic Explosivity Index $(\mathrm{VEI}) \leq 2$. VEI is index that explains the scale of explosive eruption. Costa et al. [2012] recorded that the Merapi eruptions in 1832, 1849,1930 , and 1961 are moderate eruption with VEI 3, Merapi eruptions in 1822, 1872 are large eruption with VEI 4. The 2010 eruption is the most explosive in the last century with VEI 4 [Lavigne et al., 2000; Costa et al., 2012; Suronoet al., 2012]. VEI 1, 2, 3 and 4 give small, moderate, moderate - large and large effect respectively [Newhall and Self, 1982]. The furthest distance of VEI 1, VEI 2, VEI 3 and VEI 4 pyroclastic flow are $3.2 \mathrm{~km}, 7 \mathrm{~km}, 12 \mathrm{~km}$ and $20 \mathrm{~km}$ from the crater respectively. Almost half of history of Merapi volcano eruption recorded that Merapi erupted associated with pyroclastic event [Voight, 2000].

Pyroclastic flow and pyroclastic surge are the examples of direct volcano hazard [Tilling, 2005]. Crandell et al. [1985] and Tilling [2005] differentiated pyroclastic flow and pyroclastic surge based on its material. The solid material in pyroclastic surge is less than pyroclastic flow and it has low density. Pyroclastic flow and pyroclastic surge originated from explosive eruption and dome collapse [Crandell, 1985; Newhall, 2000]. Pyroclastic flow streams and touches the ground surface and follows the topographic depression such as valley. The maximum temperature when it deposited could be reached $350{ }^{\circ} \mathrm{C}$ to more than $550{ }^{\circ} \mathrm{C}$. The size of pyroclastic flow and pyroclastic surge affected area is depending on the energy eruption and the flow velocity of pyroclastic flow and pyroclastic surge. The effect of pyroclastic flow and pyroclastic surge to environment depend on its falling materials, the temperature and the distance of area to the volcano [Crandell et al., 1985; Tilling, 2005].

The impact of 2010 Merapi eruption on the ecosystem is huge. The Bureau of Merapi Volcano National Park [2011a] reported that over 2000-2500 Ha (31-39\%) of Merapi Volcano National Park (MVNP) ecosystem which is located on Merapi volcano was destroyed. As a national park, MVNP has an important role as nature conservation area and provider of environmental services, as stipulated in Government Regulation Number 28 Year 2011 and Number 49 Year 2011. In addition, carbon sequestration in the national park is becoming a priority of forest development in the future. This study aims to know the effect of pyroclastic flow and surge to carbon stock in MVNP.

Satellite imagery for the estimation of carbon stock is widely used recently. The most accurate method to estimate carbon stock is destructive method by cutting and weighing the tree parts. Since it is time consuming and only restricted to small areas and small size of tree sample, the allometric equation which correlates tree diameter at breast height $(\mathrm{DBH})$ or others tree variable with standing wood volume or total biomass can be applied [Ketterings et al., 2001].

Medium resolution optical data is more appropriate to generate carbon stock in a simple homogeneous forest stand structure than in a complicated forest stand [Lu, 2005]. On the other hand, physical dimensions of individual trees are recognized by high-resolution satellites which can be correlated to above ground biomass. High resolution satellite imagery such as QuickBird, IKONOS, WorldView, and GeoEye can distinguish individual tree crowns so correlation between physical dimensions of trees, such as tree crown projection area, and biomass can be acquired [Gonzales et al., 2010]. Allometric equation could be used as a link since carbon stock cannot directly generate from satellite imagery.

Research was conducted in Merapi Volcano National Park (MVNP). It is located in Central Java and Yogyakarta Province. The 6410 hectare-MVNP is established by government through The Forestry Ministerial Decree Number 134/MENHUT-II/2004 dated 4th of May 2004.

Figure 1 shows the pyroclastic flow deposit over the past 95 years. More than half area of MVNP located in area with range $7 \mathrm{~km}$ from the crater. West part, southwest and small area in south part of MVNP is located in range $<12 \mathrm{~km}$ from the crater (Figure 1).

Two satellite data of MVNP that were used in the study which are QuickBird, from National Land Agency of Central Java Province recorded in 11 September 2006 and GeoEye, recorded 11 June 2011 from Gadjah Mada University. The two series satellite imagery were needed since this study analyze the carbon stock change in MVNP due to pyroclastic flow and pyroclastic surge. The rehabilitation map of MVNP from Bureau of Merapi Volcano National Park [2011b] was used to identify the rehabilitation area and the land cover map of MVNP was used to identify the broadleaf and Pine trees areas. The map of 2010 pyroclastic flow and pyroclastic surge [Darmawan, 2012] was used to identify the area affected by 2010 eruption.

\section{The Methods}

To get the model of CPA and $\mathrm{DBH}$, the fieldwork was done by measuring the $\mathrm{DBH}$ and crown diameter of the tree which was the same with the segmented tree. The CPA which was obtained from the image is the result of the segmentation process. The segmentation process was run using eCognition software. Segmentation process was applied both to 2006 Quickbird and 2011 Geoeye. The image was segmented into objects based on several criteria such as scale, color, smoothness and compactness. Object based image segmentation of high resolution satellites imagery could recognize physical dimensions of individual trees such as crown projection area (CPA).

Hierarchy classification was applied in this research with tree levels of classification. The first level has a purpose to distinguish no data (cloud, shadow, and zero value of digital number), non-vegetation and vegetation. On second level vegetation classes were divided into trees class and non-trees class. The 


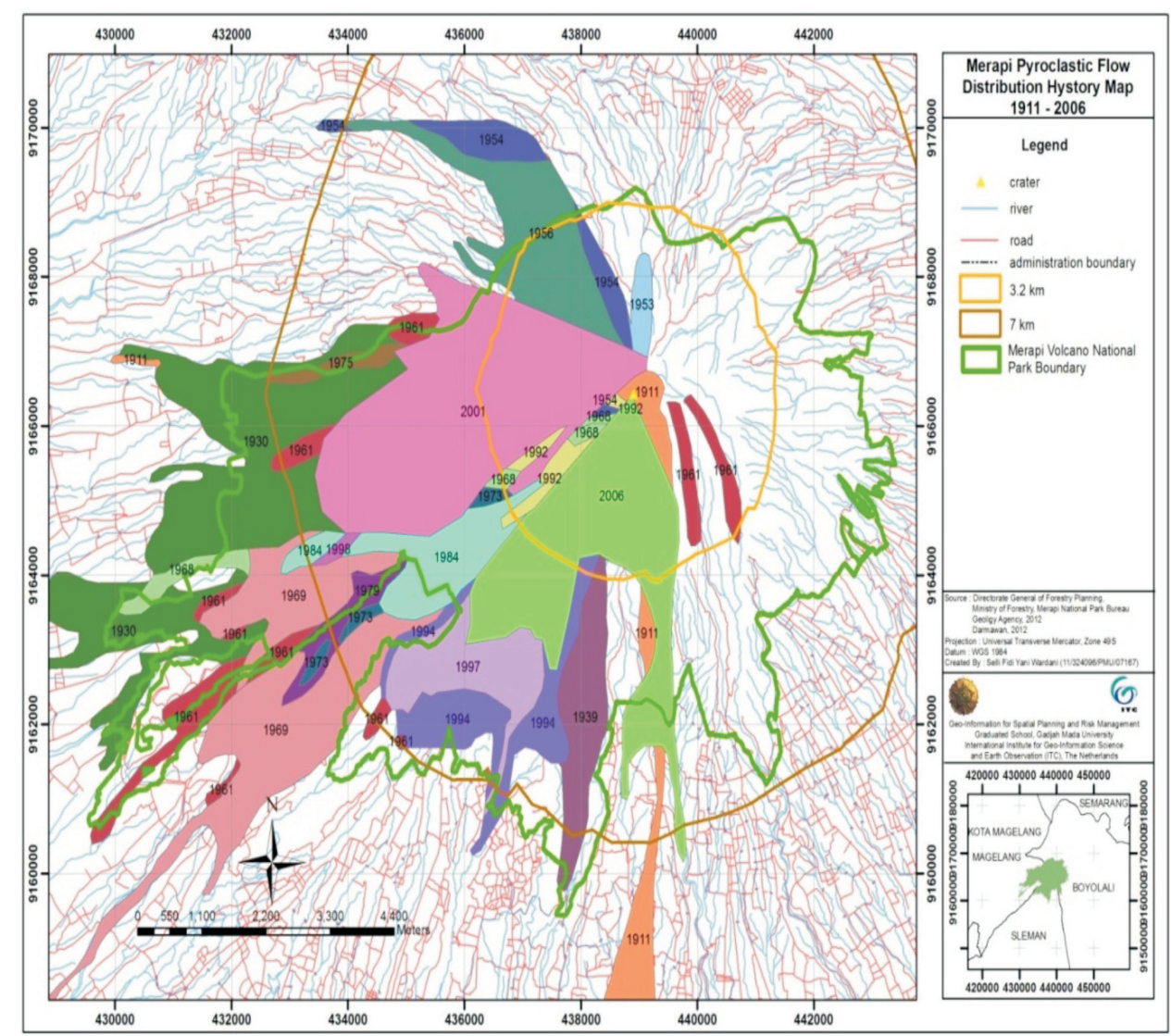

Figure1. Merapi Pyroclastic Flow Distribution Hystory Map 1911 - 2006 (Rupa Bumi Indonesia Map, Kaliurang Sheet, 1:25000; Directorate General of Forestry Planning, Ministry of Forestry; Geology Agency; Darmawan, 2012)

third class has a purpose to determine distribution of broadleaf and needle leaf at the third level.

The result of segmentation was validated by fitting the segmented CPA with manual digitizing CPA of the trees. The result of segmentation was categorized as matching with the real object if it overlaps by at least $50 \%$ with the result of manual digitizing. Figure 2 shows the condition of $50 \%$ matching object. Figure $2 \mathrm{a}$ is the condition of overlapping object more than $50 \%$, Figure $2 \mathrm{~b}$ represents the matching objects which has same size and shape but differ in position, Figure $2 \mathrm{c}$ and $2 \mathrm{~d}$ illustrates the overlapped object which match in position but differ in spatial extent [Zhan et al., 2005].

$\mathrm{Li}$ et al. [2012] categorized the accuracy of segmentation into 3 types which are true positive (TP) if the object is correctly segmented, false negative/ omission error ( $\mathrm{FN})$ if the object assigned to the nearby object, the last type is false positive/commission error (FP) if the object does not exist but it was segmented. TP, FN and FP will lead to perfect segmentation, undersegmentation, and over-segmentation, respectively.

Goutte and Gaussier [2005]. Sokolova et al. [2006], as cited in $\mathrm{Li}$ et al. [2012] calculated the accuracy based on the value of recall/r which represents object detection rate (Equation 1), precision/p which represents the correctness of the detected object (Equation 2), and F-score which indicates the overall accuracy taking both commission and omission errors into consideration (Equation 3). The range of $\mathrm{r}, \mathrm{p}$ and $\mathrm{F}$ score is $0-1$. Higher values indicate higher accuracy of segmentation.
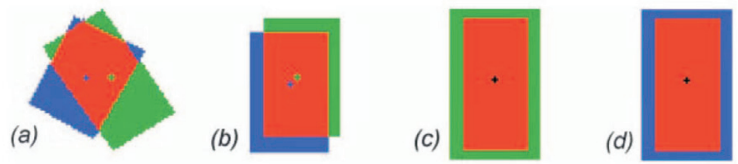

Figure 2. The overlapping Object in Segmentation Process [Zhan et al., 2005]

$\mathrm{r}=\mathrm{TP} /(\mathrm{TP}+\mathrm{FN})($ equation 1$)$

$\mathrm{p}=\mathrm{TP} /(\mathrm{TP}+\mathrm{FP})($ equation 2$)$

$\mathrm{F}=2 \mathrm{x}(\mathrm{r} \times \mathrm{p}) /(\mathrm{r}+\mathrm{p})$ 
Modified Brown allometric equations were used to estimate above ground woody biomass in MVNP. Since forest cover in MVNP are Pine forest, mixed forest and secondary forest Brown equation for tropical moist hardwoods (Equation 4) and tropical pines (Equation 5) [IPCC, 2003] were applied. MVNP which has average rainfall by $2500-3000 \mathrm{~mm} /$ year [Bureau of Merapi Volcano National Park, 2011c] is classified as moist climatic zone [Brown, 1997].

$\mathrm{Y}=\exp \left[-2.289+2.649 . \operatorname{In}(\mathrm{DBH})-0.021 .(\operatorname{In}(\mathrm{DBH}))^{2}\right]($ equation 4$)$

$\left.\mathrm{Y}=0.887+\left[\left(10486 .(\mathrm{DBH})^{2.84}\right) /\left((\mathrm{DBH})^{2.84}\right)+376907\right)\right]($ equation 5)

where:

$\mathrm{Y}=$ aboveground dry matter, $\mathrm{kg}$ (tree)-1

$\mathrm{DBH}=$ diameter at breast height, $\mathrm{cm}$

$\ln =$ natural logarithm

$\exp =$ "e raised to the power of"

The number of needle leaf trees which were measured in the field is 60 and the number of broadleaf trees that were measured is 58 trees. The trees which were collected were the same trees with the result of crown segmentation of 2011 GeoEye satellite imagery. The $60 \%$ of the measured field data (DBH) was used to build the model and $40 \%$ was used to validate the model [Gill et al., 2000].

Linear, logarithmic, quadratic and power regression were applied to build model of $\mathrm{DBH}$ and CPA regression and CPA and carbon regression. Error of the model developed was calculated to estimate the difference of carbon stock model and carbon stock of field measurement (Equation 6). The model which has the lowest error was chosen to estimate the carbon stock [Chave et al., 2005].

Error $=100 \mathrm{x}($ Carbonpredict-Carbonmeasured $) /$ Carbonmeasured (Equation 6)

Areas of pyroclastic flow and pyroclastic surge were divided into 3 (three) classes based on the surface distance to the Merapi volcano crater. The size of sampling plots was $10 \mathrm{~m}$ x $10 \mathrm{~m}$ for poles, dead woods and dead trees with diameter $10 \mathrm{~cm}$ to $<20 \mathrm{~cm}$. Trees, dead woods and dead trees with diameter $\geq 20 \mathrm{~cm}$ were registered in plot $20 \mathrm{~m}$ x $20 \mathrm{~m}$. The study focused on pole and tree stages since they give high contribution on carbon stock. Seedlings give less contribution to carbon stock [Mandal et al., 2012].

The dead trees biomass can be estimated by multiplying the allometric equation with correction factor with the intactness of the dead tree [Manuri et al., 2011]. The intactness factor of dead trees without leaves (Figure $3 a$ ) is 0.9 , the intactness factor of dead trees without leaves and twigs is 0.8 (Figure $3 \mathrm{~b}$ ) and the intactness factor of dead trees without leaves, branches and twigs is 0.7 (Figure 3c).

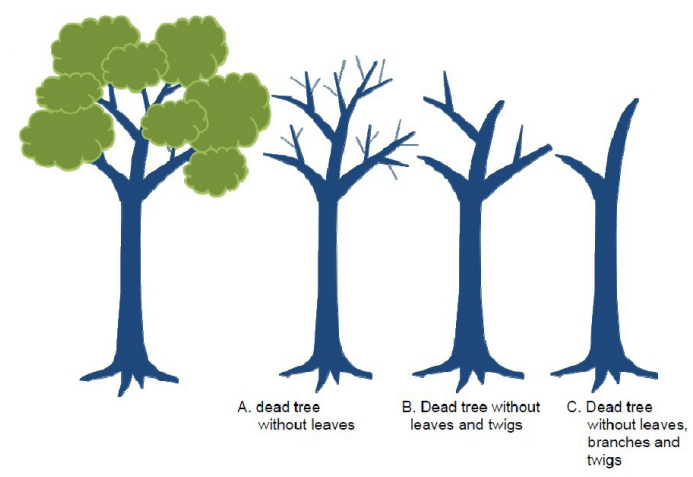

Figure 3. Intactness Level of Dead Trees [SNI 7724:2011, 2011]

To estimate carbon of the dead wood, diameter of base and tip and the total length of dead wood were measured. Dead wood biomass is influenced by its volume and its wood density (Equation 7 and Equation 8) [SNI 7724:2011, 2011].

$B_{\mathrm{dw}}=V_{\mathrm{dw}} \times W D_{\mathrm{dw}}($ equation 7$)$

$\mathrm{V}_{\mathrm{dw}}=0.25 \Pi\left(\mathrm{d}_{\mathrm{b}}+\mathrm{d}_{\mathrm{t}} / 2 \mathrm{x} 100\right)^{2} \times \mathrm{p}$ (equation 8$)$

Note:

Vdw is the volume of dead wood (m3);

dbis the diameter of the base of the dead wood $(\mathrm{cm})$; $\mathrm{dtis}$ the diameter of the tip of the dead wood $(\mathrm{cm})$; pis the length of the dead wood $(\mathrm{m})$;

$\pi$ is $22 / 7$ or 3.14

$\mathrm{Bdw}$ is the dead wood biomass $(\mathrm{kg})$;

WDdw is the dead wood density $(\mathrm{kg} / \mathrm{m} 3)$.

The wood density of dead wood was generated by collecting the wood samples from the field and analyzed in laboratory. The wood samples were classified based on their decomposition levels which are good, moderate and decomposed. The numbers of wood samples for each decomposition level were 10 . Based on the laboratory analysis, the wood densities of dead wood with good, moderate and decomposed level of wood decomposition rate were $0.65,0.56$ and 0.55 $\mathrm{kg} / \mathrm{m} 3$ respectively.

The rate of carbon recovery was established based on relation between age and carbon stock of recovery area. Age was derived from pyroclastic flow events at different times by delineating the historic map of pyroclastic flow in MVNP. The estimation of carbon stock in recovery area was done by applied the developed model of CPA-carbon of broadleaved to recovery area.

The artificial carbon rate recovery cannot be measured since the rehabilitation activity in MVNP was just conducted in 2011 and 2012. Therefore the activities carried out in the rehabilitated area was monitoring of carbon stocks. The estimation of rehabilitation trees was done in Kalikuning, Selo, Deles (area rehabilitation 2011) and Ngargomulyo (area rehabilitation 2012). 
The DBH and CPA of saplings, poles and trees of dominant trees in MVNP were collected in the field in order to know the pattern of the growth of DBH, CPA and carbon of dominant trees in MVNP.

Based on the fieldwork, the identified dominant trees in MVNP are Schima wallichii, Erythrina variegata, Lithocarpus elegans, Pinus merkusii, Altingia excelsa and Acacia decurrens. The DBH and CPA of sapling were measured in random $5 \mathrm{~m} \mathrm{x} 5 \mathrm{~m}$ plots and poles were measured in random $10 \mathrm{~m} \times 10 \mathrm{~m}$ plots. By knowing their diameter increment their age will be generated. The diameter increment of dominant trees was obtained based on literature study.

The relation of DBH and age of Pinus merkusii, Altingia excelsa and Acacia decurrens was develop based on the yield table. Relation between DBH and age of Schima wallichii, Erythrina variegata, and Lithocarpus elegans was develop based on DBH measurement in the field because they are not in the list of yield table (Table 2).

Table 1. Sampling Plot Number of Pyroclastic Flow and Pyroclastic Surge Area and Their Distribution

\begin{tabular}{lrrrr}
\hline Location & Surface Distance $(\mathbf{m})$ & ID & Number of Plots & Area (ha) \\
\hline Pyroclastic Flow & $>3973-5297$ & Class 2 & 15 & 94 \\
Pyroclastic Flow & $>5297-6620$ & Class 3 & 15 & 23 \\
Pyroclastic Flow & $>6620-7945$ & Class 4 & 15 & 31 \\
Pyroclastic Surge & $>2650-3973$ & Class 1 & 15 & 98 \\
Pyroclastic Surge & $>3973-5297$ & Class 2 & 15 & 213 \\
Pyroclastic Surge & $>5297-6620$ & Class 3 & 15 & 95 \\
\hline
\end{tabular}

Table 2. Mean Diameter Increment and Relation of Age and CPA Field of Dominant Trees in MVNP

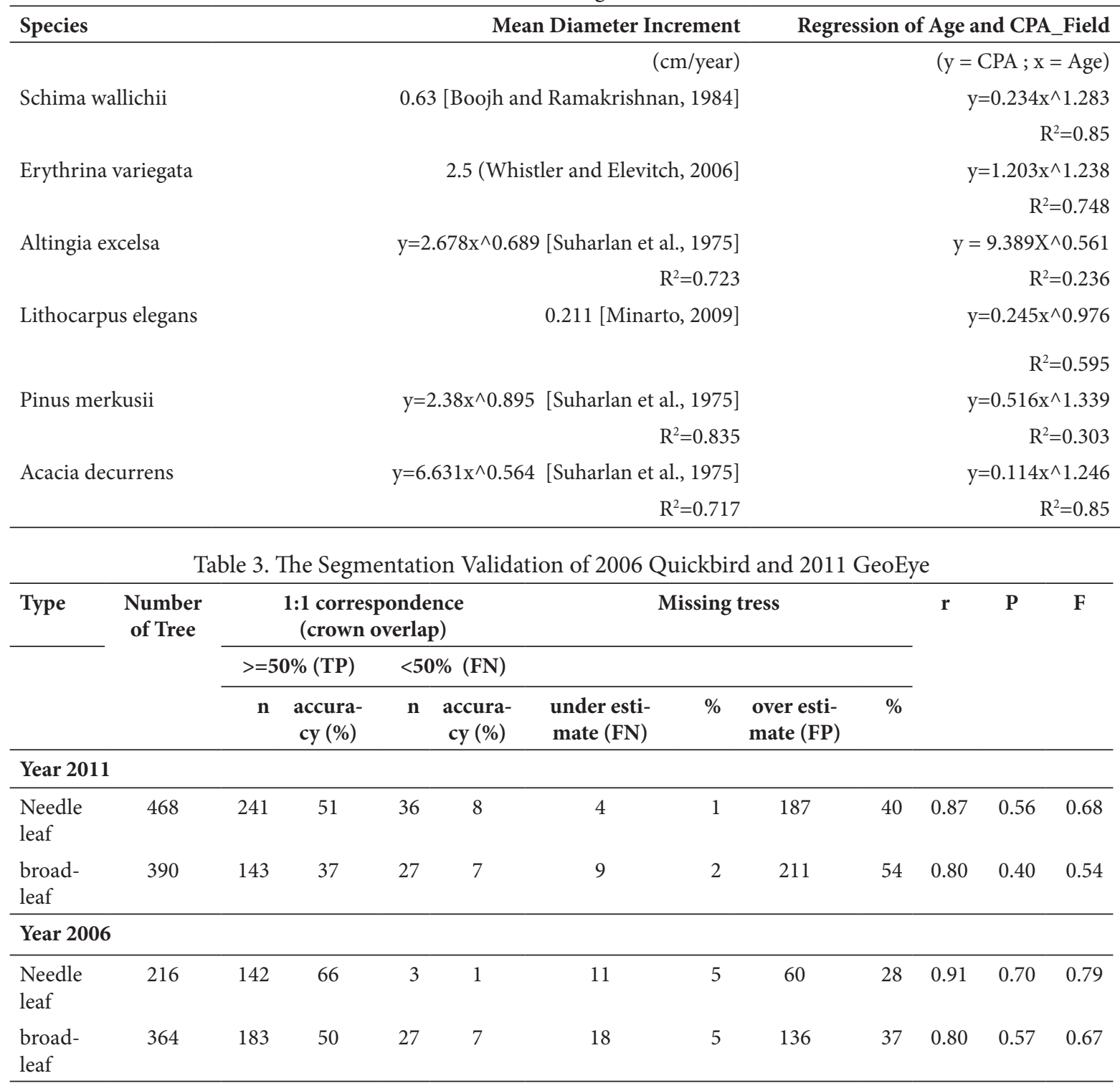


Table 4. Developed Model of DBH-CPA and CA-Carbon of Broadleaved and Pine Trees

\begin{tabular}{|c|c|c|}
\hline Developed Model & $\mathrm{R}^{2}$ & Error $(\%)$ \\
\hline \multicolumn{3}{|l|}{ Broadleaved } \\
\hline \multicolumn{3}{|l|}{ a) $\mathrm{DBH}-\mathrm{CPA}$} \\
\hline -Linear $(\mathrm{DBH}=-0.069 \mathrm{CPA}+42.121)$ & 0.023 & 3.18 \\
\hline- Logarithmic $(\mathrm{DBH}=-2.213 \ln \mathrm{CPA}+46.426)$ & 0.015 & $2.67^{\star}$ \\
\hline -Quadratic $\left(\mathrm{DBH}=-0.001 \mathrm{CPA}^{\wedge} 2+0.048 \mathrm{CPA}+39.990\right)$ & 0.028 & 6.55 \\
\hline -Power $\left(\mathrm{DBH}=46.652 \mathrm{CPA}^{\wedge}-0.083\right)$ & 0.036 & 11.85 \\
\hline \multicolumn{3}{|l|}{ b) CPA-Carbon } \\
\hline -Linear $($ Carbon $=-0.964 \mathrm{CPA}+898.544)$ & 0.001 & 7.28 \\
\hline -Logarithmic $($ Carbon=10.648lnCPA+819.302) & 0.00007 & $6.37^{\star}$ \\
\hline -Quadratic $\left(\right.$ Carbon $\left.=-0.13 \mathrm{CPA}^{\wedge} 2+16.791 \mathrm{CPA}+576.517\right)$ & 0.027 & 16.68 \\
\hline -Power $($ Carbon=912.006CPA^^-0.209) & 0.037 & 50.73 \\
\hline \multicolumn{3}{|l|}{ Pine } \\
\hline \multicolumn{3}{|l|}{ a) $\mathrm{DBH}-\mathrm{CPA}$} \\
\hline -Linear $(\mathrm{DBH}=0.104 \mathrm{CPA}+41.462 \mathrm{R} 2=0.053)$ & 0.053 & 5.97 \\
\hline -Logarithmic $(\mathrm{DBH}=5.461 \operatorname{lnCPA}+27.457 \mathrm{R} 2=0.097)$ & 0.097 & 6.12 \\
\hline -Quadratic $\left(\mathrm{DBH}=-0.005 \mathrm{CPA}^{\wedge} 2+0.725 \mathrm{CPA}+31.065 \mathrm{R} 2=0.207\right)$ & 0.207 & $2.86^{*}$ \\
\hline -Power $(\mathrm{DBH}=31.359 \mathrm{CPA} \wedge 0.098 \mathrm{R} 2=0.077)$ & 0.077 & 10.00 \\
\hline \multicolumn{3}{|l|}{ b) CPA-Carbon } \\
\hline -Linear $($ Carbon $=3.954 \mathrm{CPA}+504.154)$ & 0.063 & 15.28 \\
\hline -Logarithmic $($ Carbon= 203.547lnCPA-14.874) & 0.110 & 15.59 \\
\hline- Quadratic $\left(\right.$ Carbon $\left.=-0.186 \mathrm{CPA}^{\wedge} 2+26.013 \mathrm{CPA}+134.692\right)$ & 0.221 & $10.31^{\star}$ \\
\hline -Power $($ Carbon $=240.370 \mathrm{CPA} \wedge 0.222)$ & 0.068 & 33.89 \\
\hline
\end{tabular}

Table 5. Carbon stock of Broadleaved and Pine Tree Based on CPA-Carbon Developed

\begin{tabular}{|c|c|c|c|c|c|c|c|c|}
\hline \multirow[t]{3}{*}{ Year } & \multicolumn{2}{|c|}{$\begin{array}{c}\text { Total Carbon Stok (kg/ } \\
\text { ha) }\end{array}$} & \multicolumn{2}{|c|}{$\begin{array}{c}\text { Carbon in Unaffected } \\
\text { Area }(\mathrm{kg} / \mathrm{ha})\end{array}$} & \multicolumn{4}{|c|}{ Carbon Stock (kg/ha) } \\
\hline & \multirow[t]{2}{*}{ Pine } & \multirow[t]{2}{*}{ Broadleaves } & \multirow[t]{2}{*}{ Pine } & \multirow[t]{2}{*}{ Broadleaves } & \multicolumn{2}{|c|}{ Pyroclastic Flow Area } & \multicolumn{2}{|c|}{ Pyroclastic Sugre Area } \\
\hline & & & & & Pine & Broadleaves & Pine & Broadleaves \\
\hline 2011 & 142,782 & 142,699 & 143,528 & 145,951 & 9,414 & 48,343 & 72,402 & 128,473 \\
\hline 2006 & 114,336 & 121,336 & 116,301 & 121,676 & 102,673 & 50,497 & 113,849 & 152,920 \\
\hline
\end{tabular}

\section{Result and Discusion}

The validation of segmentation based on Zhan et al. [2005] and Li et al. [2012] is presented in Table 3. It was done in order to know the accuracy of segmentation. $\mathrm{F}$ score which indicate the accuracy of segmentation was above 0.5 means that the accuracy of algorithm which was used to segment the object can be applied.

Developed model of CPA-Carbon Broadleaved and Pine Trees based on Linear, Logarithmic, Quadratic and Power regression and its error are presented in Table 4. The Table 4 shows that logarithmic regression model has the lowest value of error for CPA-Carbon relation of broadleaves trees (equation 9). And the model which has the lowest error for CPA-Carbon relationship of Pine trees is quadratic (polynomial order 2) (equation 10). Thus, the models used in this research are:
Developed Model of CPA-Carbon Relation of Broadleaved Trees

Carbon $=10.648 \ln C P A+C P A+819.302$ (equation 9)

Developed Model of CPA-Carbon Relation Pine Trees

Carbon $=-0.86 \mathrm{CPA}^{\wedge} 2+26.013 \mathrm{CPA}+134.692$ (equation 10$)$

Carbon stock of Broadleaved and Pine Tree is presented in Table 5. Based on the field observation, dead trees and dead wood which were found in the field was Pine trees. So Pine allometric equation was used to estimate the dead trees carbon stock. In the pyroclastic flow area there were no poles and trees. The only tree stage that was found in the pyroclastic flow area was Acacia decurrens in sapling stage. Acacia decurrens is the pioneer which is grown in MVNP after the eruption. 


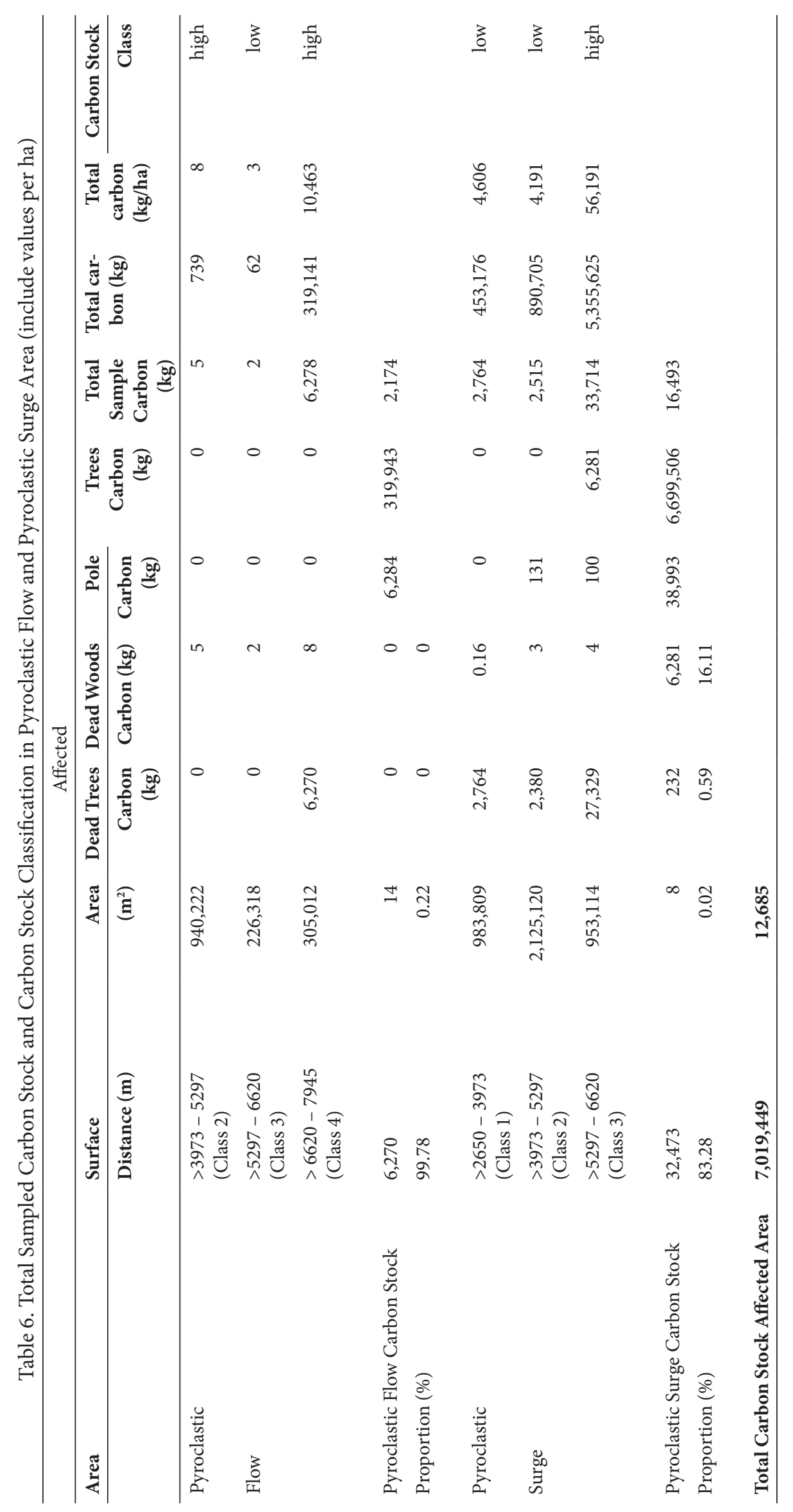


In pyroclastic surge area, there were Schima wallichii and Acacia decurrens in pole stage. The tree stage which was found in surge area was Pine. The result of carbon stock estimation in affected area is presented in Table 6.

Total carbon loss in pyroclastic area was estimated by subtracting carbon stocks that were likely to have been in the affected areas by remaining carbon stock in affected area. In this case total carbon loss was estimated based on subtracting of 2006 carbon stock that were likely to have been in the affected areas by the remaining carbon stock based on field measurement. The total carbon loss was $405,100 \mathrm{~kg}$.

The carbon rate recovery was generated based on relation between age of pyroclastic flow event as independent variable and carbon stock in recovery areas as dependent variable. The 2011 CPA-Carbon developed model was applied to estimate carbon stock in recovery area. Linear, Power, Quadratic and Logistic regression was built to relate age of pyroclastic flow event and carbon stock in recovery areas (Table 7).

Rehabilitation activity in MVNP was carried out in 2011 and 2012 (Table 8).

The DBH, CPA and Carbon of dominant trees in MVNP in first year of their life and sixth year of their life are presented in Table 9.

Based on paired sample T-test, the CPA and Carbon stock of dominant trees in MVNP of first year is not different with the CPA and Carbon stock of dominant trees in MVNP of sixth year. While the first year and sixth year of DBH of dominant trees in MVNP is significantly different.

Total remaining carbon stock in affected area based on field measurement was lower than carbon stock based on CPA-Carbon model. This can be due to the overestimation of segmented crown. Though there was an over segmentation but overall the accuracy of segmentation based on the calculation of F score which indicate the accuracy of segmentation was above 0.5 means that the accuracy of algorithm which was used to segment the object more than $50 \%$ and the model can be applied to estimate carbon stock [Li et al., 2012].

The over segmentation can occur due to the algorithm approach and some parameters which were used such as shape, texture and digital number (both of mean and standard deviation) in segmentation process were not give a good result. Some objects that were actually not the tree were recognized as a tree by the algorithm and the parameters because it has similar characteristics with canopy such as the rocky land with small vegetation cover.

The uncertainty of tree segmentation can be caused by the spacing threshold of the trees. However, determination of appropriate in dense forests is difficult. The high threshold will lead to under-segmentations and low threshold lead to over segmentations [Carleer et al., 2005; Li et al., 2012].

The CPA-Carbon relation was developed based on segmented CPA of 2011 GeoEye satellite imagery. The attribute value of 2011 GeoEye satellite imagery will influence to quality of imagery and affect the carbon estimation. The sun elevation angle at acquisition time was $49^{\circ} 43^{\prime}$ and the sun azimuth angle was $39^{\circ} 42^{\prime}$. Sensor azimuth angle was $78^{\circ} 31^{\prime}$ and sensor elevation angle was $67^{\circ} 45^{\prime}$ means the off-nadir angle of the 2011 was $22^{\circ} 14^{\prime}$ [Astrand, 2011]. High nadir angle [Meixner and Leberl, 2010] and low sun elevation [Jacobsen and Büyüksalih] will result to oblique image. Based on sun elevation and off-nadir angle, the 2011 GeoEye satellite

Table 7. Regression Model of the Age of Pyroclastic Flow and Carbon Stock in MVNP Recovery Areas

\begin{tabular}{llr}
\hline No & Regression Model & $\mathbf{R}^{2}$ \\
\hline 1 & Quadratic $y=0.005 \mathrm{x} 2-0.468 \mathrm{x}+15.12$ & 0.418 \\
2 & Linear $\mathrm{y}=0.025 \mathrm{x}+7.402$ & 0.013 \\
3 & Power $\mathrm{y}=12.88 \mathrm{x}-0.18$ & 0.035 \\
4 & Logistic $\mathrm{y}=1 / 0.135^{\star} 1.002 \mathrm{x}$ & 0.004 \\
\hline
\end{tabular}

Table 8. Carbon Stock in Rehabilitation Trees

\begin{tabular}{llllllll}
\hline $\begin{array}{l}\text { Rehabilitation } \\
\text { Area }\end{array}$ & $\begin{array}{l}\text { Year of } \\
\text { Rehabilita- } \\
\text { tion }\end{array}$ & $\begin{array}{l}\text { Seedling } \\
\text { Sampling } \\
\text { Carbon } \\
\text { Stock }(\mathbf{k g})\end{array}$ & $\begin{array}{l}\text { Seedling } \\
\text { Carbon } \\
\text { Stock }(\mathbf{k g})\end{array}$ & $\begin{array}{l}\text { Sapling } \\
\text { Sampling } \\
\text { Carbon } \\
\text { Stock }(\mathbf{k g})\end{array}$ & $\begin{array}{l}\text { Sapling } \\
\text { Carbon } \\
\text { Stock }(\mathbf{k g})\end{array}$ & $\begin{array}{l}\text { Total } \\
\text { Carbon } \\
\text { Stock }(\mathbf{k g})\end{array}$ & $\begin{array}{l}\text { Total } \\
\text { Carbon } \\
\text { Stock } \\
\left(\mathbf{k g} / \mathbf{m}^{2}\right)\end{array}$ \\
\hline $\begin{array}{l}\text { Gandog } \\
\text { Tegalmulyo }\end{array}$ & 2011 & 0.08 & 666 & 2 & 3406 & 4071 & 0.006 \\
$\begin{array}{l}\text { Selo } \\
\text { Total Rehabilitation Carbon Stock }\end{array}$ & 2011 & 0.07 & 247 & 2 & 1468 & 1715 & 0.006 \\
$\begin{array}{l}\text { Ngargomulyo } \\
\text { Total Rehabilitation Carbon Stock }\end{array}$ & & 0.06 & 293 & 0.01 & 11 & 304 & 0.002 \\
\hline
\end{tabular}


Table 9. The First and Sixth Year of DBH, CPA and Carbon Stock of Dominant Trees in MVNP

\begin{tabular}{|c|c|c|c|c|c|c|}
\hline Species & DBH $(\mathrm{cm})$ & $\mathrm{CPA}\left(\mathrm{m}^{2}\right)$ & Carbon (kg) & & & \\
\hline & Year 1 & Year 6 & Year 1 & Year 6 & Year 1 & Year 6 \\
\hline $\begin{array}{l}\text { Schima wal- } \\
\text { lichii }\end{array}$ & 0.6 & 3.8 & 0.5 & 2.3 & 0.01 & 0.1 \\
\hline $\begin{array}{l}\text { Erythrina } \\
\text { variegata }\end{array}$ & 2.5 & 15 & 1.2 & 11.1 & 0.5 & 3.2 \\
\hline $\begin{array}{l}\text { Altingia } \\
\text { excelsa }\end{array}$ & 2.7 & 16.1 & 3.5 & 25.7 & 0.6 & 3.8 \\
\hline $\begin{array}{l}\text { Lithocarpus } \\
\text { elegans }\end{array}$ & 0.2 & 1.3 & 0.6 & 1.4 & 0.001 & 0.004 \\
\hline $\begin{array}{l}\text { Acacia de- } \\
\text { currens }\end{array}$ & 6.6 & 39.8 & 0.4 & 1.3 & 6.6 & 39.8 \\
\hline $\begin{array}{l}\text { Pinus } \\
\text { merkusii }\end{array}$ & 2.4 & 14.3 & 0.8 & 5.7 & 0.6 & 3.4 \\
\hline
\end{tabular}

imagery is oblique and the crown projection area was elongated. Those conditions affect the accuracy of carbon stock estimation in MVNP.

In this study, the highest carbon stocks of dead trees were located in pyroclastic flow and surge in surface distance class farthest from the crater. Area with surface distance class 4 had high amount of dead trees carbon stock because the area is far from the crater so the speed and temperature of pyroclastic flow has decreased [Crandell et.al, 1984; Darmawan, 2012; Surono et al., 2012].

Carbon stock in pyroclastic surge area was higher than carbon stock in pyroclastic flow. In pyroclastic surge area also found poles and trees biomass. That is because pyroclastic flow material is more destructive than pyroclastic surge material. The density of cloud of gases and rock debris of pyroclastic surge is lower than pyroclastic flow. Pyroclastic flow carried hot volcanic materials. The temperature maximum that can be reached by pyroclastic flows is around $350^{\circ} \mathrm{C}$ to more than $550^{\circ} \mathrm{C}$ when it deposited. Since pyroclastic flow is more powerful and its temperature is higher than pyroclastic surge material, pyroclastic fow can cause all the trees are downed and more damaging than pyroclastic surge [Crandell et al., 1984].

The remaining carbon stock in affected area was underestimated since there was utilization of dead trees and dead wood in affected area by the community to rebuilt their damaged house by the eruption and utilize it for fire wood.

Linear regression was selected to developed model of natural carbon rate recovery in MVNP by considering the $4-6$ years Merapi volcano eruption period. Study by Peper et al. [2001] concluded that the DBH and CPA growth is fast on its 15 years first but slow in its 15 years second. Since the Merapi volcano eruption period is 4 - 6 years which is below the first stage of tree life, 15 years, the carbon growth in MVNP will increase in 4-6 years Merapi volcano eruption period.Therefore linear regression was chosen to correlate age of pyroclastic flow event and carbon stock in recovery area.
The artificial carbon rate recovery cannot be developed since there was only 1 year growth data of rehabilitation trees. Plants that were used to rehabilitate the MVNP are Schima wallichii, Erythrina variegate, Syzygium cumini and Inocarpus fagiferu which need light for their live (intolerant species) [Harja et al., 2012; Whistler and Elevitch, 2006; Sheikh, 1993; Pauku, 2006]. Based on the fieldwork, reeds were growth in the rehabilitation area and cause their growth is slow and some of rehabilitation trees is dead.

The estimation of carbon rate recovery was estimated based on CPA-Carbon model of 2011 GeoEye satellite imagery. It was difficult to validate the data of carbon stock in recovery area since the eruption is the past event. The carbon stock in recovery area will affect the estimation of natural carbon rate recovery in MVNP. Vegetation structure may have changed in the past and the remaining carbon stock of survival trees in recovery area could also count as carbon recovery. That would affect the accuracy of estimation carbon stock in recovery area.

\section{Conclusion}

Since 19th century Merapi volcano erupts 4-6 years periodically. The 4-6 years Merapi period eruption has $\mathrm{VEI} \leq 2$ with the deposit of pyroclastic flow $\leq 7 \mathrm{~km}$ from the crater. The directions of pyroclastic flow are varies. All area of MVNP is on the range of $\leq 7 \mathrm{~km}$ pyroclastic flow deposit. The southwest and west part of MVNP is in the range of VEI 3 with $12 \mathrm{~km}$ pyroclastic flow deposit. That conditions makes the MVNP is always susceptible to pyroclastic flow event. This condition will be the problem because the role of national park as nature conservation area and provider of environmental services and play a role in carbon sequestration in the future based on Government Regulation Number 28 Year 2011 and Number 49 Year 2011will be disrupted.

\section{Recommendation}

During the study, there are some ideas that can be developed and recommended for further research of 
carbon stock in MVNP. 1) The use of good quality high resolution satellite imagery will improve the accuracy of carbon stocks estimation based on CPA-Carbon relationship. Integrating the high resolution image with LiDAR can be considered to estimate carbon stock in MVNP, 2) The further research about artificial carbon rate recovery is recommended since there is not enough data series to establish the relationship between time and artificial carbon stock when this study was conducted, 3) The use of accurate land cover map after 2010 eruption will increase the accuracy of broadleaf

\section{References}

Astrand, P. J. (2011), VHR image acquisition specifications for the CAP controls (CwRS and LPIS QA). Ispra, European Commission Joint Research Centre Institute for Environment and Sustainability Monitoring Agricultural Resources Unit.

Bureau of Merapi Volcano National Park, Ministry on Forestry (2011a), Survey of vegetation and wild fauna in Merapi Volcano National Park after eruption in 2010 (in bahasa), Directorate General of Forest Protection and Nature Conservation, Ministry of Forestry, Yogyakarta.

Bureau of Merapi Volcano National Park, Ministry on Forestry (2011b), Map album of national park ecosystem restoration after the eruption of Mount Merapi in 2010 (in bahasa), Directorate General of Forest Protection and Nature Conservation, Ministry of Forestry, Yogyakarta.

Bureau of Merapi Volcano National Park, Ministry on Forestry (2011c), Physical condition (in bahasa), http://tngunungmerapi.org/?page_id=215, Accessed date: 24-May-2012.

Brown, S. (1997), Estimating biomass and biomass change of tropical forests: a primer, http://www. fao. org/docrep/w4095e/w4095e00.htm, Access da-te: 6-November-2012.

Carleer, A.P., Debeir, O., \& Wolff, E. (2005), Assessment of very high spatial resolution satellite image segmentations, Photogrammetric Engineering \& Remote Sensing Journal 71: 1285-1394.

Chave, J., Andalo, C., Brown, S., Cairns, A., Chambers, J. Q., Eamus, D., Folster, H., Fromard, F., Higuchi, N., Kira, T., Lescure, J. P., Nelson, W., Ogawa, H., Puig, H., Rie'ra, B., \& Yamakura, T. (2005), Tree allometry and improved estimation of carbon stocks and balance in tropical forests, Oecologia 145(1): 87-99.

Costa, F., Andreastuti, S., Bouvet de Maisonneuve, C., \& Pallister, J. S. (2012), Petrological insights into the storage conditions, and magmatic processes that yielded the centennial 2010 Merapi explosive eruption. Journal of Volcanology and Geothermal Research, in press, corrected proof.

Crandell, D. R., Booth, B., Kusumadinata, K., Shimozuru, D., Walker, G. P. L. \& Westercamp, D. (1984), and Pine tree carbon stock estimation, 4) Further study of regeneration will give more accurate results in natural carbon rate recovery in MVNP, 5) The map of Merapi volcano susceptible area in MVNP is needed to create good planning of rehabilitation and restoration in MVNP.

\section{Acknowledgement}

Thank to Prof. Junun Sartohadi, M.Sc for valuable comments and his support during the research and thanks to review for the constructive comments.

Source-book for volcanic-hazards zonation, UNES$\mathrm{CO}$, France.

Darmawan, H. (2012), Pyroclastic flow modeling using TITAN2D to predict pyroclastic hazards post Merapi Volcano eruption 2010 (in bahasa), MSc thesis, Gadjah Mada University.

Geology Agency. Un-dated. Merapi history (in bahasa). URL: http://merapi.bgl.esdm.go.id/ informasi_merapi.php?page=informasimerapi\&subpage=sejarah. Accessed date: 17-November-2012

Gill, S. J., Biging, G. S., Murphy, E. C. (2000), Modeling conifer tree crown radius and estimating canopy cover, Forest Ecology and Management 126:405416.

Intergovernmental Panel on Climate Change (IPCC) (2003), Good practice guidance for land use, landuse change and forestry, Institute for Global Environmental Strategies, Kanagawa.

Intergovernmental Panel on Climate Change (IPCC) (2007), Climate change 2007: synthesis report, The Intergovernmental Panel on Climate Change, Geneva.

Intergovernmental Panel on Climate Change (IPCC) (2012), Managing the risks of extreme events and disasters to advance climate change adaptation. Cambridge: Cambridge University Press.

Jacobsen, K., \& Büyüksalih G. Un-dated. Topographic mapping from space, http://www.ipi.uni-hannover. de/uploads/tx_tkpublikationen/Jacobsen_istanbul_01.pdf. Accessed date: 4-February-2013.

Ketterings, Q. M., Coe, R., van Noordwijk, M., Ambagau, Y., \& Palm, C. A. (2001), Reducing uncertainty in the use of allometric biomass equations for predicting above-ground tree biomass in mixed secondary forests, Forest Ecology and Management 146(1-3): 199-209.

Lavigne, F., Thouret, J. C., Voight, B., Suwa, H., \& Sumaryono, H. (2000), Lahars at Merapi Volcano, Central Java: an overview, Journal of Volcanology and Geothermal Research 100(1-4): 423-456.

Li, W., Guo, Q., Jakubowski, M. K., \& Kelly, M. (2012), A new method for segmenting individual trees from the lidar point cloud, Photogrammetric Engineering 
\& Remote Sensing 78: 75-84.

Lu, D. (2005), Integration of vegetation inventory data and Landsat TM image for vegetation classification in the western Brazilian Amazon, Forest Ecology and Management 213: 369-383.

Mandal, R. A., Dutta, I. C., Jha, P. K., Karmacharya, S., yadav, K., Thapa, U., \& Haque, S. (2012), Effects of deforestration anf forest degradation on forest carbon stock in collaborative forests, Nepal, International Journal Of Conservation Science 3 (4): 325338.

Manuri, S., Putra, C. A. S., \& Saputra, A. D. (2011), Forest carbon stock estimation techniques (in bahasa), Merang REDD Pilot Project - German International Cooperation (MRPP-GIZ), Palembang.

Meixner, P., \& Leberl, F. (2010), Interpreting building facades from vertical aerial images using the third dimension, In ISPRS Technical Commission IV \& AutoCarto Symposium ASPRS/ CaGIS 2010 Fall Specialty Conference. ISPRS, Orlando.

Minarto, E. (2009), Forest dynamics of peat swamp forest in Sebangau, Central Kalimantan, Biodiversitas 10: 187-194.

Newhall, C. G., \& Self, S. (1982), The Volcanic Explosivity Index (VEI) - an Estimate of Explosive Magnitude For Historical Volcanism, Journal of Geophysical Research-Oceans and Atmospheres 87: 1231-1238.

Newhall, C. G., Bronto, S., Alloway, B., Banks, N. G., Bahar, I., del-Marmol, M. A., Hadisantono, R. D., Holcomb, R. T., McGeehin, J., Miksic, J. N., Rubin, M., Sayudi, S. D., Sukhyar, R., Andreastuti, S., Tilling, R. I., Torley, R., Trimble, D., \& Wirakusumah, A. D. (2000), 10,000 Years of explosive eruptions of Merapi Volcano, Central Java: archaeological and modern implications, Journal of Volcanology and Geothermal Research 100(1-4): 9-50.

Pauku, R. L. (2006), Species Profiles for Pacific Island Agroforestry-Inocarpus fagifer (Tahitian chestnut), http://agroforestry.net/tti/Inocarpus-Tahitian chestnut.pdf. Accessed date: 5-March-2013.
Sheikh, M. I. (1993), Trees of Pakistan, http://pdf.usaid. gov/pdf_docs/pnabw250.pdf: 5-March-2013.

SNI 7724:2011 (2011), Measurement and calculation of carbon stocks - field measurement for estimating forest carbon stocks (ground based forest carbon accounting), Standardization and Enviroment, Ministry of Forestry.

Suharlan, A., Sumarna, K., \& Sudiono, J. (1975), Yield Table of ten industrial wood species, Forestry Research and Development Agency, Ministry of Forestry, Bogor.

Surono, Jousset, P., Pallister, J., Boichu, M., Buongiorno, M. F., Budisantoso, A., Costa, F., Andreastuti, S., Prata, F., Schneider, D., Clarisse, L., Humaida, H., Sumarti, S., Bignami, C., Griswold, J., Carn, S., Oppenheimer, C., \& Lavigne, F. (2012), The 2010 explosive eruption of Java's Merapi volcano-A '100year' event, Journal of Volcanology and Geothermal Research 241-242: 121-135.

Tilling, R. I. (2005), Volcano Hazards, In Marti, J and Ernst, G. G. J, Volcanoes and The Environment, pp 55-89. Cambridge University Press.

Voight, B., Constantine, E. K., Siswowidjoyo, S., \& Torley, R. (2000), Historical eruptions of Merapi Volcano, Central Java, Indonesia, 1768-1998, Journal of Volcanology and Geothermal Research 100: 69-138.

Whistler, W. A., \& Elevitch, C. R. (2006), Species Profiles for pacific island agroforestry-erythrina variegata (coral tree), http://agroforestry.net/tti/Erythrinacoraltree.pdf. Accessed date: 13-January-2013.

Zhan, Q., Molenaar, M., Tempfli, K., \& Shi, W. (2005), Quality assessment for geo-spatial objects derived from remotely sensed data, International Journal of Remote Sensing 26: 2953-297. 